\title{
APPLICATION OF GIS IN MODELING ZILBERCHAI BASIN RUNOFF
}

\author{
L. Malekani $^{\text {a, }}$, S. Khaleghi ${ }^{\text {b* }}$, M. Mahmoodi ${ }^{c}$ \\ a Dept. of Civil Engineering, University of Tabriz, Tabriz, Iran - lmalekani@tabrizu.ac.ir \\ ${ }^{b}$ Dept. of Geography, University of Tabriz, Tabriz, Iran - s.khaleghi@ tabrizu.ac.ir \\ ${ }^{c}$ Dept. of Geography and Urban Planning, University of Tarbiat Modares, Tehran, Iran-mehranmahmoodi1390@gmail.com
}

KEY WORDS: Runoff Modelling, SCS method, GIS, Arc Hydro, ArcCN-Runoff, Zilberchai basin

\begin{abstract}
:
Runoff is one of most important hydrological variables that are used in many civil works, planning for optimal use of reservoirs, organizing rivers and warning flood. The runoff curve number $(\mathrm{CN})$ is a key factor in determining runoff in the SCS (Soil Conservation Service) based hydrologic modeling method. The traditional SCS-CN method for calculating the composite curve number consumes a major portion of the hydrologic modeling time. Therefore, geographic information systems (GIS) are now being used in combination with the SCS-CN method. This work uses a methodology of determining surface runoff by Geographic Information System model and applying SCS-CN method that needs the necessary parameters such as land use map, hydrologic soil groups, rainfall data, DEM, physiographic characteristic of the basin. The model is built by implementing some well known hydrologic methods in GIS like as ArcHydro, ArcCN-Runoff for modeling of Zilberchai basin runoff. The results show that the high average weighted of curve number indicate that permeability of the basin is low and therefore likelihood of flooding is high. So the fundamental works is essential in order to increase water infiltration in Zilberchai basin and to avoid wasting surface water resources. Also comparing the results of the computed and observed runoff value show that use of GIS tools in addition to accelerate the calculation of the runoff also increase the accuracy of the results. This paper clearly demonstrates that the integration of GIS with the SCS-CN method provides a powerful tool for estimating runoff volumes in large basins.
\end{abstract}

\section{INTRODUCTION}

The determination of the runoff value is necessary for designing of dams, reservoir management and prediction of risks and potential losses caused by flooding. Also determining amount of the runoff is very important in projects related to sediment and erosion processes. There are various methods for estimating runoff in the basins that they have not enough data. Curve Number method (SCS-CN) is one of the most widely used approaches for fast and accurate calculation of the basin surface runoff. This approach involves the use of a simple empirical formula and readily available tables and curves. A high curve number means high runoff and low infiltration; whereas a low curve number means low runoff and high infiltration. The curve number is a function of land use and hydrologic soil group (HSG). It is a method that can incorporate the land use for computation of runoff from rainfall (Shadeed and Almasri, 2010).

Also this method has been used more and provides accurately automatic runoff prediction by connected with the Geographical Information System (GIS). In recent decades, most researchers have considered the use of GIS (Patil 2008). There are many models such as WMS, SWAT, EPIC, AGNPS, MIKE 11, MIKE FLOOD, HEC GeoHMS etc. in the water and environmental research that have combined well with GIS and in these models the SCS-CN method is used to determine hydrological parameters (Zhan 2004, Kopp and Noman 2008). SCS method based on GIS was used in many studies for estimating runoff such as Ramakrishnan et al (2009) identify potential water harvesting areas by the SCS-CN and GIS in the Kali watershed, Mahi River basin of India. Rao et al. (2010) estimated surface runoff in an agricultural watershed of India using SCS-CN and spatial information technologies (GIS and RS). Xiao et al (2011) predicted runoff of small basin in China using SCS-CN method and spatial information technologies (GIS and RS). Compare the results with the observed value based on the standard Nash-Sutcliffe coefficien and the error ratio indicate that this method has high accuracy. Also Mishra and Singh (2003), Ramasubramaniam et al (2008), Ebrahimian and Abdul Malek (2009), Amutha and Porchelvan (2009), Domnita et al (2010), Dhawale (2013), estimated runoff with SCS method and they are used GIS to obtain the factors for determining runoff depth and curve number and in all of these studies, the results have been satisfactory. According to above in this study, Zilberchai runoff is estimated by using GIS tools including ArcCN-Runoff for determining curve number of the basin that is based on land use and hydrological soil groups, interpolation tool (IDW) for determining 24-hour rainfall for the basin as a raster, raster calculator for determining runoff height based on SCS methods and ArcHydro for calculating runoff.

Zilberchai basin located in estern Azarbaijan between $45^{\circ}, 04^{\prime}$, $44^{\prime \prime}$ to $55^{\circ}, 33^{\prime}, 50^{\prime \prime}$ eastern longitude and $38^{\circ}, 18^{\prime}, 09^{\prime \prime}$ to $38^{\circ}$, 40, 57" northern latitude (Figure 1). Zilberchai River is formed by joining Zonouzchai and Ajichai Rivers that it reaches to Ghotourchai in the north west of basin and the exit point which after that is called Zilberchai. Table 1 shows physiographic characteristics of Zilberchai basin and drainage area. The morphology of the basin mainly includes plains and mountains, which hills unit are located in some parts of the two geomorphologic units junction. This basin is located in temperate mountainous area that has cold and dry climate with very cold winters and temperate summers. 


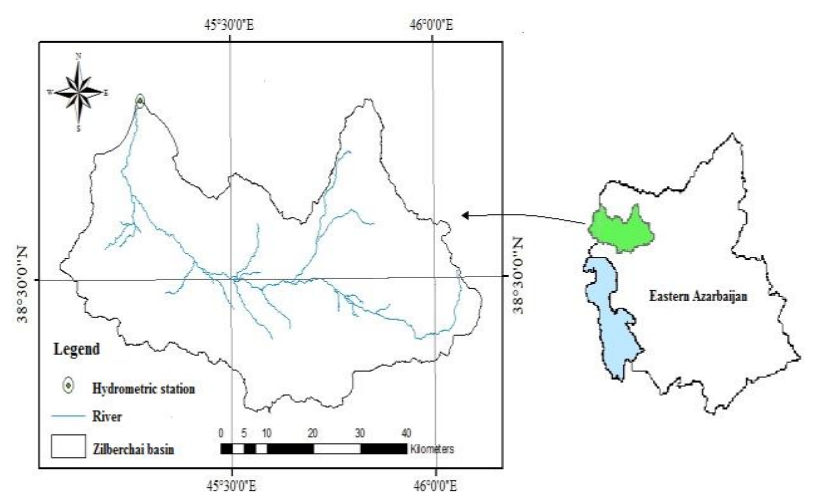

Figure 1. The location of the study area

\begin{tabular}{|c|c|}
\hline Physiographic characteristics & value \\
\hline Area $\left(\mathrm{km}^{2}\right)$ & 2612.021 \\
Perimeter $(\mathrm{km})$ & 314.12 \\
Weighted average slope $(\%)$ & 18.35 \\
Maximum height $(\mathrm{m})$ & 3229.7 \\
Minimum height $(\mathrm{m})$ & 926.4 \\
Time of concentration & 11.4 \\
Total length of stream $(\mathrm{km})$ & 13671.1 \\
Length of largest stream $(\mathrm{km})$ & 114.2 \\
Maximum height of the longest (m) & 2815.6 \\
Minimum height of the longest (m) & 926.4 \\
Stream Slope (\%) & 1.7 \\
\hline
\end{tabular}

Table 1.Physiographic characteristics of Zilberchai basin

There are two hydrometric stations in Zilberchai basin, Pole Charchar station in Zonouzchai River and Mozaffarabad station (at outlet of the basin) in Zilberchai (available data from 19842011). The statistical characteristics of the rainfall and runoff data are presented in Table 2.

In this study, a GIS was employed as a tool to calculate the composite curve number for Zilberchai basin and to estimate the $\mathrm{CN}$, soil retention coefficient, runoff coefficient and finally runoff height and volume based on spatially varying soil and land use information.

\begin{tabular}{|c|c|c|c|c|}
\hline $\begin{array}{c}\text { Hydrological } \\
\text { parameters }\end{array}$ & Average & Max & Min & $\begin{array}{c}\text { Standard } \\
\text { deviation }\end{array}$ \\
\hline Zonouzchai rainfall & 282.8 & 445.5 & 199.6 & 63.5 \\
\hline Mozaffarabad rainfall & 212.8 & 420 & 125.5 & 72.5 \\
\hline Zonouzchai runoff & .2 & .7 & 0 & .2 \\
\hline Mozaffarabad runoff & .8 & 2.7 & .3 & .6 \\
\hline
\end{tabular}

Table 2. Statistical characteristics of annual rainfall and runoff

\section{MATERIAL AND METHODS}

The Flowchart in figure 1 depicts the overall methodology for the GIS-based SCS-CN method utilized in this study. In this method, land use and soil map and annual rainfall of the study and hydrologic methods in GIS like as ArcHydro, ArcCN-
Runoff, Interpolation tools and raster calculator were used for preparing all of data for estimating runoff.

\subsection{SCS-CN method}

SCS method estimates the runoff according to rainfall and characteristics of basins. So it is appropriate for estimating runoff where there isn't any station for the flow measurement in the basin. The SCS empirical method proposed by the U.S. Soil Conservation Service is widely used for estimating direct runoff. The SCS method that is also well known as curve number method is based on water balance.

$P=I_{a}+F+Q$

Where $P$ is rainfall $(\mathrm{mm}), \mathrm{I}_{\mathrm{a}}$ is Initial abstraction $(\mathrm{mm}), \mathrm{F}$ is cumulative infiltration other than $\mathrm{I}_{\mathrm{a}}(\mathrm{mm}), \mathrm{Q}$ is direct runoff $(\mathrm{mm})$. Initial abstraction $\left(\mathrm{I}_{\mathrm{a}}\right)$ is function of the maximum potential abstraction (S). The following equation is using for estimating Runoff:

$Q=\frac{\left(P-I_{a}\right)^{2}}{P+S-I_{a}}$

Equation (2) is true for $\mathrm{P}>\mathrm{I}_{\mathrm{a}}$, otherwise the estimated runoff to be zero. Initial retention $\left(I_{a}\right)$ is in fact part of the precipitation that does not participate in the runoff and is considered equal to $\mathrm{I}_{\mathrm{a}}=0.2 \mathrm{~S}$ in SCS:

$R=\frac{(P-0.2 S)^{2}}{P+0.8 S}$

The potential maximum retention(S) is determined based on curve number $(\mathrm{CN})$ from the following equation:

$\mathrm{S}=\frac{2540}{\mathrm{CN}}-25.4 \quad(\mathrm{~mm})$

In this case $\mathrm{CN}$ is the curve number that depends on some factors such as hydrologic soil groups, vegetation and watershed land use (Chow, 1988).

\subsection{Accuracy of results}

Finally computed runoff and observed runoff can be compared for valuation of accuracy by tree criterions (Nash-Sutcliffe model efficiency coefficient (E), correlation coefficient (R2) and root-mean-square error (RMSE)). Note that the correlation coefficient $\left(\mathrm{R}^{2}\right)$ can be calculated as:

$$
R^{2}=\frac{\sum_{i=1}^{N}\left(Q_{m i}-\bar{Q}_{m}\right)\left(Q_{p i}-\bar{Q}_{p}\right)}{\left(\sum_{i=1}^{N}\left(Q_{m i}-\bar{Q}_{m}\right)^{2}\right)^{0.5}\left(\sum_{i=1}^{N}\left(Q_{p i}-\bar{Q}_{p}\right)^{2}\right)^{0.5}}
$$

At coefficient of efficiency (E) account for model errors in estimating the mean or variance of the observed data sets. $\mathrm{E}$ 
range from minus infinity (poor model) to 1.0 (perfect model), and can be calculated as

$E=1.0-\frac{\sum_{i=1}^{N}\left(Q_{m i}-Q_{p i}\right)^{2}}{\sum_{i=1}^{N}\left(Q_{m i}-\bar{Q}_{m}\right) 2}$

In other to objectively evaluate the model performance, the most commonly employed error measure, such as the rootmean-square error (RMSE) can be computed for the model.
$R M S E=\sqrt{\sum_{i}^{N} \frac{\left(Q_{m i}-Q_{p i}\right)^{2}}{N}}$

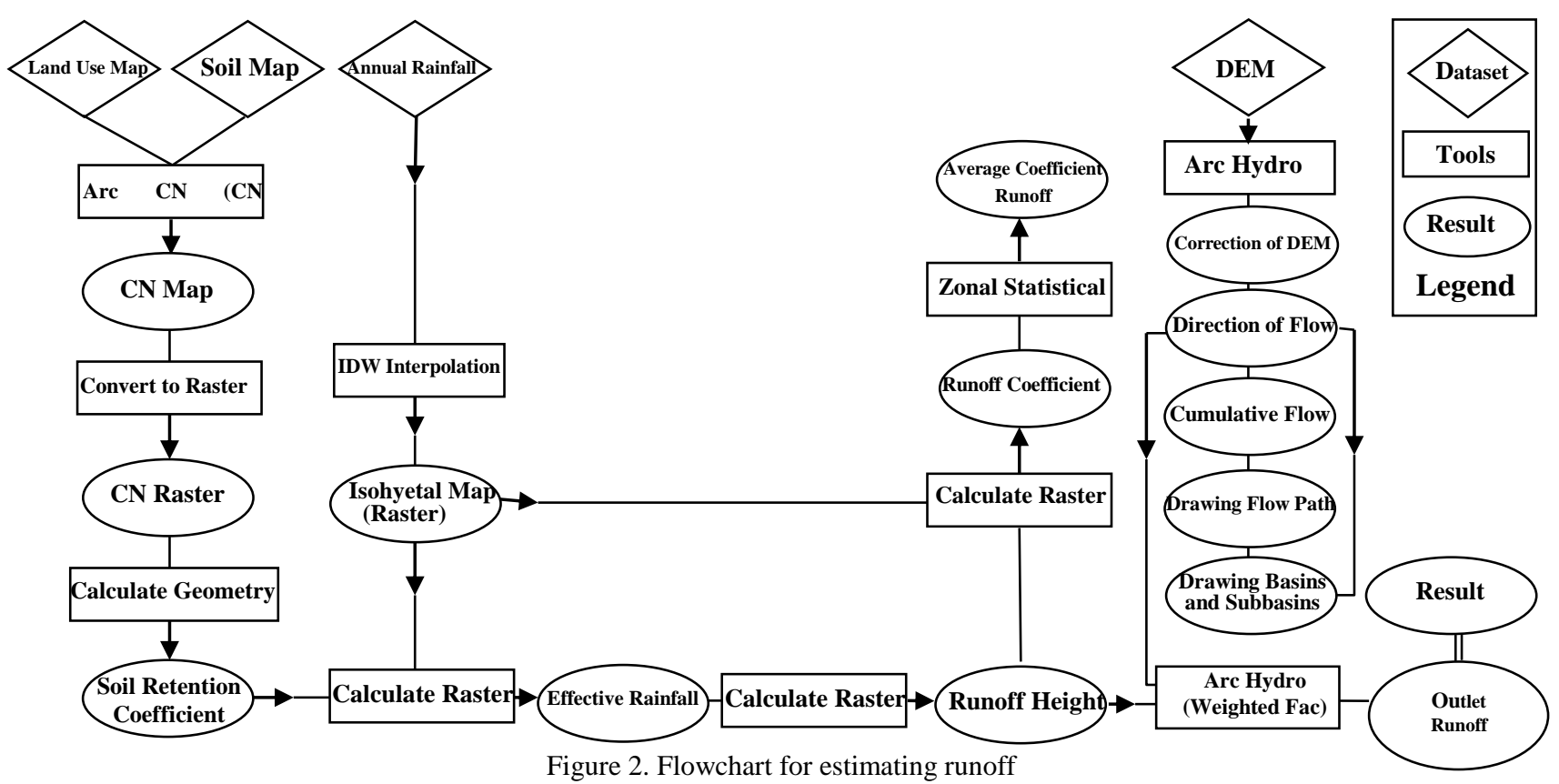

\section{RESULT AND DISCUSSION}

\subsection{Curve Number}

$\mathrm{CN}$ is calculated based on the physical characteristics of the basin, hydrological soil groups, land use, hydrologic conditions and antecedent soil moisture condition. $\mathrm{CN}$ is the most important parameter in SCS method that should be determined accurately. In recent decades, with the development and utilization of GIS in hydrological models, there are different tools. One of these tools is ArcCN-Runoff that was introduced by Zhang et al. (2004). To calculate $\mathrm{CN}$ of Zilberchai basin, the available land use and soil type maps were processed using GIS techniques $(\mathrm{ArcCN})$ to determine the hydrological soil groups map based on a definition of SCS Hydrologic Soil Groups. Land use map of the basin is creating by Ministry of Jihad Agriculture (2008) using ETM+ landsat image of year 2003 and supervised classification of land use with definition of maximum likelihood algorithms and GIS. Finally land use map (figure 3) was extracted with $93 \%$ overall accuracy. Table 3 shows the type and the area of different land use of Zilberchai basin. The most of the Zilberchai basin area is weak pasture that this kind of land use has poor hydrological condition and low infiltration.

\begin{tabular}{|c|c|}
\hline Type of Land Use & Area $\left(\mathrm{Km}^{2}\right)$ \\
\hline Dense Pasture & 291 \\
Moderate Pasture & 662 \\
Weak Pasture & 1040 \\
Rainfed farm & 131 \\
Irrigated farm & 31 \\
Irrigated farm with salinity restriction & 13 \\
Mixed Pasture and Rainfed farm & 376 \\
Tree integrate & 87 \\
Residential area & 1 \\
\hline
\end{tabular}

Table 3. Land uses in Zilberchai basin 


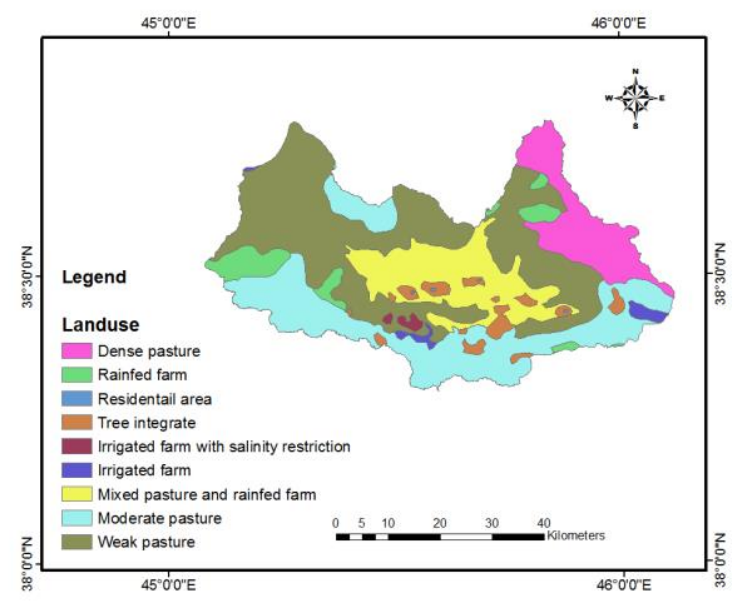

Figure 3. Land use map of Zilberchai basin

Finally, the hydrological soil groups map was prepared based on soil map that has information about soil depth and texture characteristics. Figure 4 shows a hydrological soil groups map of Zilberchai basin and table 4 is given the area of each of these groups that indicates high percent $\left(1479.49 \mathrm{Km}^{2}\right)$ of Zilberchai basin area is D type with very low permeability.

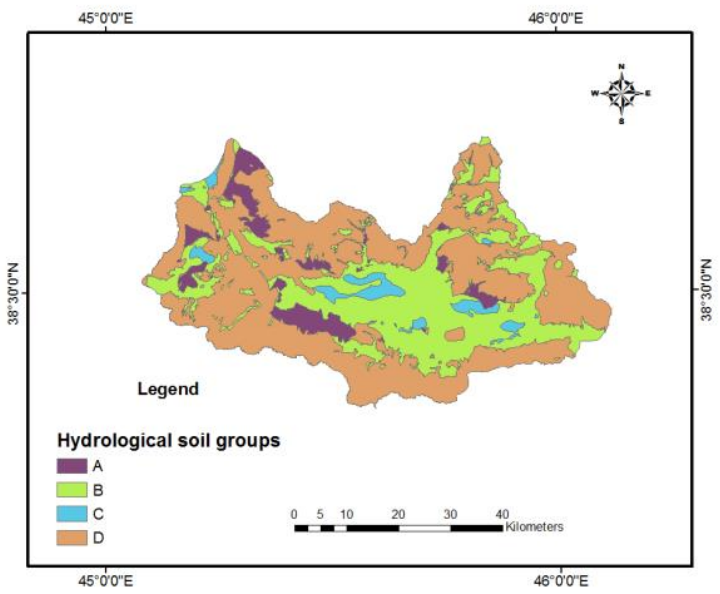

Figure 4. Hydrological soil groups of Zilberchai basin

\begin{tabular}{|c|cccc|}
\hline $\begin{array}{c}\text { Hydrologic } \\
\text { al Group }\end{array}$ & A & B & C & D \\
\hline Area $\left(\mathrm{Km}^{2}\right)$ & 178.853 & 860.187 & 93.490 & 1479.49 \\
\hline \multicolumn{4}{|c|}{$\begin{array}{l}\text { A (High Permeability), B (Moderate Permeability), C (Low } \\
\text { Permeability), D (Very Low Permeability) }\end{array}$} \\
\hline
\end{tabular}

Table 4. The Area of Hydrological Soil Groups in Zilberchai basin

Since calculating curve number for the large basin such as Zilberchai will be difficult without using GIS techniques, therefore in $\mathrm{ArcCN}$, the curve number map for each polygon is created by combining land use (figure 3 ) and hydrologic soil group map (figure 4) and utilizing the index table of curve numbers (for each of soil hydrologic groups is determined by land use type) (figure 5). Table 6 shows statistical properties of Zilberchai basin curve number that have been calculated by Zonal Statistical tool. Figure 5 and table 5 show that the most part of the basin has high curve number. It means that permeability of the basin is low.

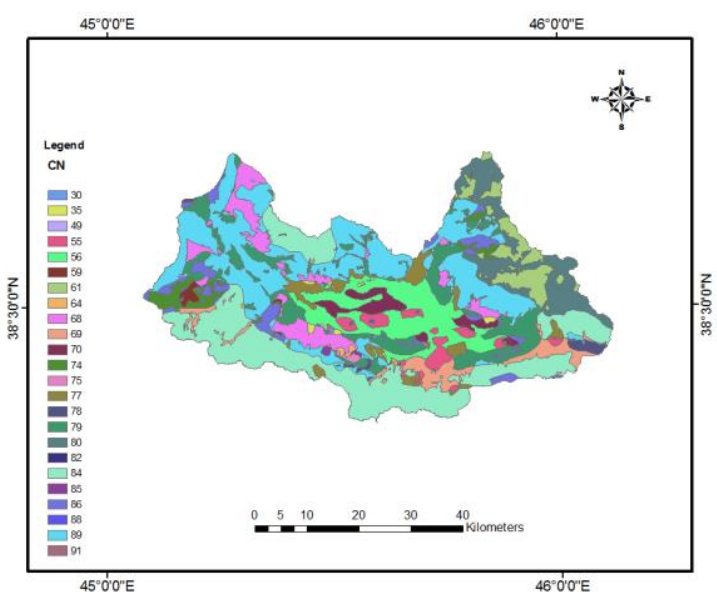

Figure 5. The curve number map of Zilberchai Basin

\begin{tabular}{|c|c|c|c|c|}
\hline Count & Maximum & Minimum & Average & $\begin{array}{c}\text { Standard } \\
\text { Deviation }\end{array}$ \\
\hline 32377 & 91 & 31 & 77.51 & 11.279 \\
\hline
\end{tabular}

Table 5. Statistical Characteristics of Curve Number

Finally the potential maximum retention $(S)$ is determined based on curve number map (5) and equation 4 in ArcGIS (figure 6). The potential maximum retention in the Zilberchai basin is low except some parts.

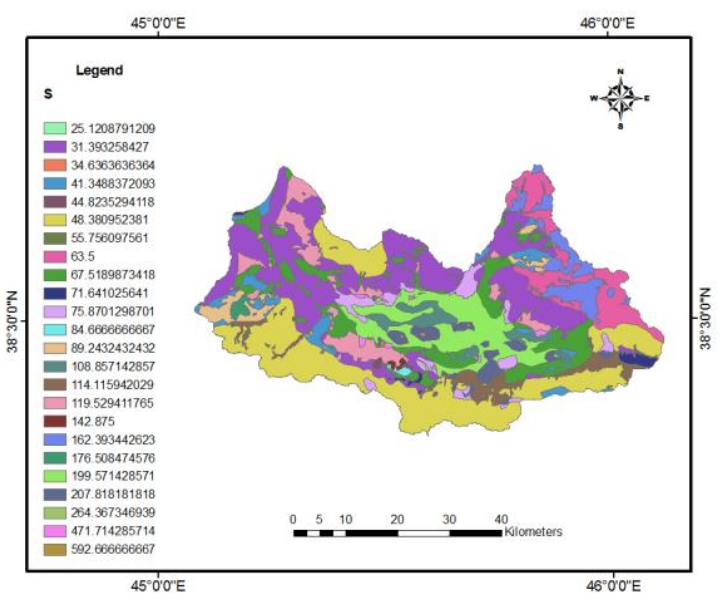

Figure 6. Soil retention coefficient map of Zilberchai Basin

\subsection{Rainfall}

Interpolation process is called to obtain the unknown points from the known points. There are three ways such as IDW, Spline, Kriging for interpolation in GIS. In IDW method, the unknown pixels is estimated by averaging known points of the near each pixel and the values that are closer to the center of pixel that has higher weight in estimating unknown value. In this study, raster map of rainfall obtained by using the average annual rainfall of 35 rainfall and hydrometric stations located in Western and Eastern Azerbaijan and utilizing IDW interpolation method. Figure 7 shows average annual rainfall map during the period of 1984 to 2010. Maximum, minimum and average annual rainfall of Zilberchai basin is 316.245, 199.178 and $248.856 \mathrm{~mm}$ respectively. 


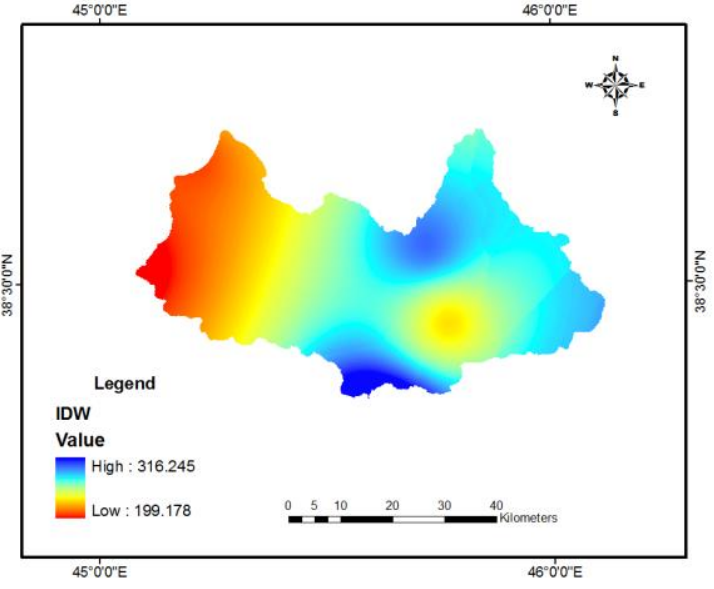

Figure 7. Raster map of rainfall created by IDW

\subsection{Runoff Coefficient and Outlet Runoff}

Raster runoff map can be obtained by several ways in GIS. The first method is to use the $\mathrm{ArcCN}$ tool which in this method, runoff height is calculated for each polygon and runoff value is obtained by using the weighted average equation for the whole basin. The second method is using the Raster Calculator tool which in this method, a raster map of runoff height can be calculated by curve number map and rainfall raster map and using the SCS equation. As observed in figure 8, discharge is rising because of the aggregated flow along the river.

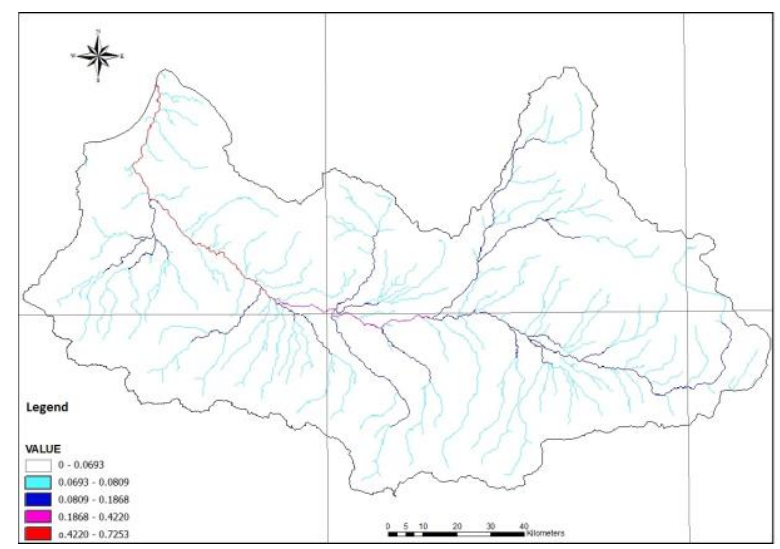

Figure 8. Amount of runoff in Zilberchai drainage basin

Also runoff coefficient map (figure 9) was obtained by dividing runoff map into the corresponding rainfall values in raster calculator. The calculated average runoff coefficient is equal to 0.71 (without subtracting with the base flow) that is high.

The runoff coefficient of Zilberchai basin is high in the most parts of the basin but in center part of basin is low.

Finally the runoff of each cell is collected from the upstream to downstream of the basin aided of runoff and aspect flow maps and utilizing ArcHydro (Weighted Fac). Results of this study show (figure 10) that the most of the Zilberchai basin area is weak pasture with poor hydrological condition. Also high percent of Zilberchai basin has D type of hydrological soil group with very low permeability and finally has high curve number. It means that the potential maximum retention in the Zilberchai basin is low and therefore likelihood of flooding is high. The average runoff coefficient is high in the most parts of the basin that is enough high to generate flood.

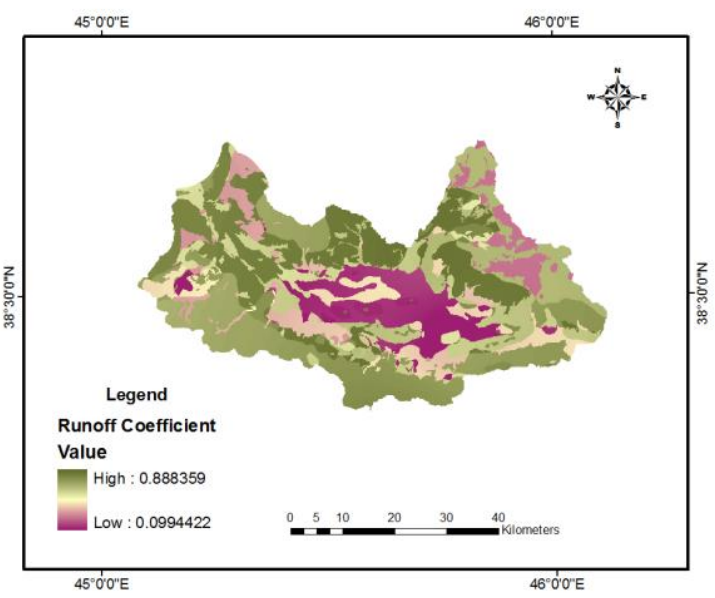

Figure 9. Runoff coefficient map of Zilberchai basin

So the fundamental works is essential in order to increase water infiltration and to avoid wasting surface water resources in Zilberchai basin.

Also the calculating runoff has high accuracy because of few reasons first; it was calculated for the dimensions of 90 by 90 meters of basin. Second; runoff height corresponding to the 27year annual rainfall (period of 1984 to 2010) was calculated for detection of GIS efficiency. Third; comparing the computed runoff and observation runoff using the correlation coefficient, Nash-Sutcliffe coefficient and root-mean-square error (RMSE) show high accuracy of the results (table 6). Finally we can use this method for calculating runoff of the basins which they have not enough hydrometric stations and we cannot use other estimating runoff methods such as intelligent, hydrologic and hydraulic models (e.g. HEC-RAS...).

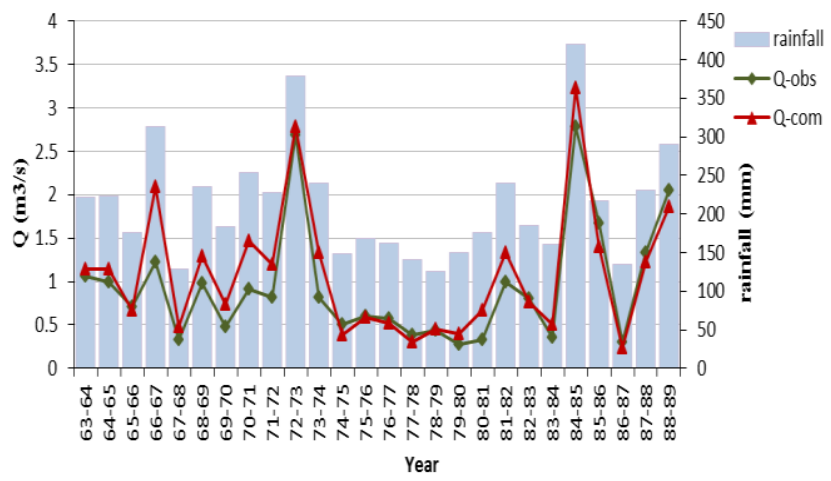

Figure 10. The result of computed and observed outlet runoff

\begin{tabular}{|c|c|c|}
\hline $\begin{array}{c}\text { Correlation } \\
\text { Coefficient } \\
\left(\mathrm{R}^{2)}\right.\end{array}$ & $\begin{array}{c}\text { Nash- } \\
\text { Sutcliffe } \\
\text { coefficient } \\
(\mathrm{E})\end{array}$ & $\begin{array}{c}\text { Root Mean Square Error } \\
\text { (RMSE) }\end{array}$ \\
\hline .87 & .80 & .34 \\
\hline
\end{tabular}

Table 6. Comparison of computed and observed runoff

\section{CONCLUSION}

This work presented a GIS-based SCS-CN to calculate the composite curve number and the runoff in a large basin such as Zilberchai basin. The model requires the input of some 
parameters related to the runoff. The results from maps prepared by GIS show that the lands with inappropriate hydrologic group and low permeability, have high runoff and discharge than the areas with appropriate hydrologic group. Also geospatial technique has high accuracy so that determining the exact curve number by GIS is cause of the high accuracy of the method. In addition to high accuracy, the main advantage of this method is determining of runoff at each point of the basin that is the basic parameters in the design of the hydraulic structures.

\section{REFERENCES}

1. Amutha R., Porchelvan P., (2009), Estimation of surface runoff in Malattar sub-watershed using SCS$\mathrm{CN}$ method. Journal of the Indian Society of Remote Senses. 37:291-304.

2. Chow, V.T., David, R.M., and Larry, W. M., 1988. Applied Hydrology. McGraw - Hill book Company, New York.

3. Dhawale, A. W., 2013. Runoff Estimation for Darewadi Watershed using RS and GIS. International Journal of Recent Technology and Engineering. 1(6), pp. 46-50.

4. Domnita, M., Ionut Craciun, A., Haidu, I., MagyariSaska, Z., 2010. GIS used for determination of the maximum discharge in very small basins (under 2 $\mathrm{km} 2$ ). Wseas Transactions on Environment and Development, volume 6, pp. 468-477.

5. Ebrahimian, M., Abdul Malek, I., 2009. Application of Natural Resources Conservation Service Curve Number Method for Runoff Estimation with GIS in the Kardeh Watershed, Iran, European Journal of Scientific Research, 34 (4), pp. 575-590.

6. Justification studies of watershed management and renewable natural resources of Zilberchai basin, (2008), Ministry of Jihad Agriculture, Administrators Forest Rangeland and Watershed Management.

7. Kopp, S., Noman, N., 2008. ArcGIS Spatial Analyst - Hydrologic Modeling, ESRI User Conference Technical Workshop, http://www.scdhec.gov/gis/presentations/ESRI_Confe rence_08/tws/workshops/tw_37.pdf, visited 25 April 2011.

8. Mishra, S. K., Singh, V. P., 2003. Soil Conservation Service Curve Number (SCS-CN) Methodology (Dordrecht, Germany: Kluwer Academic Publishers) ISBN1-4020-1132-6.

9. Patil, J. P., Sarangi, A., Singh, O. P., Singh, A. K., Ahmad, T., 2008. Development of a GIS Interface for Estimation of Runoff from Watersheds. Water Resources Management, 22(9), pp. 12211239.

10. Ramakrishnan, D., Bandopadhay, A., Kusuma, K. N., 2009. SCS-CN and GIS-based approach for identifying potential runoff harvesting sites in the Kali watershed, Mahi River basin, India. Journal of Earth System Sciences, 118 (4), pp. 355-368.

11. Ramasubramaniam, K., Pugazhendi, V., Anitha, A., Dawn, S. S., 2008. Estimation of Surface Runoff Using Geospatial Technology Kombai Micro Watershed - A Case Study. International Journal on Applied Bioengineering, 2(1), pp. 25 - 31.

12. Rao, K., Narendra, K., Latha, P., 2010. An Integrated Study of Geospatial Information Technologies for Surface Runoff Estimation in an Agricultural Watershed, India. Journal of the Indian Society of Remote Sensing, 38(2), pp. 255-267.

13. Shadeed, S., Almasri, M., 2010. Application of GISbased SCS-CN method in West Bank catchments, Palestine. Water Science and Engineering, 3(1), pp. 113.

14. Xiao, B., wang, Q.H., Fan, J., Han, F.P., Dai, Q.H., 2011. Application of the SCS-CN Model to Runoff Estimation in a Small Watershed with High Spatial Heterogeneit,. Pedosphere 21(6), pp. 738-749.

15. Zhan, X., Huang, M.L., 2004. ArcCN-Runoff: an ArcGIS tool for generating curve number and runoff maps. Environmental Modeling \& Software, 19, pp. 875-879. 